\title{
Exploring Spatial Patterns of Urban Brownfields: the Case of Daugavpils City
}

\author{
Anastasija Smoḷakova \\ Daugavpils University, Faculty of Natural Sciences and Mathematics, Department of Chemistry and Geography. \\ Address: Parades iela 1, Daugavpils, LV-5401, Latvia.
}

\begin{abstract}
Deindustrialization has been an important process in transforming the urban regions in Central and Eastern Europe. In Daugavpils, there is a long history of industry dated back to the 19th century. The massive deindustrialization of the 1990s caused increased concentrations of brownfield localities within the city. Previous studies have demonstrated that the geographic location of urban brownfields is an important factor affecting brownfields regeneration. The aim of the current study is to explore the characteristics of the brownfield sites and their spatial patterns in the city of Daugavpils. The analysis is based on a data obtained during the fieldwork. The results presented in this paper depends on survey of 61 brownfield sites in Daugavpils. Majority of local brownfields are abandoned buildings previously used for industrial and commercial activities and unevenly distributed within the city. Higher number of brownfield regeneration have been detected in densely built-up areas close to the inner-city areas, while lower rates were found for areas with low population density at the periphery of the city. The findings also suggest that urban brownfield regeneration increases the attractiveness and livability of a particular locality.
\end{abstract}

Keywords: brownfield regeneration, Daugavpils city, deindustrialization, urban brownfields.

\section{INTRODUCTION}

During the last decades of the $20^{\text {th }}$ century Europe experienced geopolitical and socioeconomic changes, including processes as of demilitarization, deagriculturization and deindustrialization [1]. While in the Western Europe these processes started to appear in the early 1970 s as a result of economic restructuring and progressed slowly, in many countries of Eastern and Central Europe they occurred rapidly in beginning of the 1990s due to collapse of socialism and the centrally planned economy [2] - [4]. As a result of these processes, increasing number of abandoned sites so-called brownfields appeared [1], [4] - [9].

In recent decades' brownfields (derelict, underused, abandoned and/or contaminated sites) has gained high attention and this term has become recognized worldwide [2], [4]. Considering reducing availability of vacant developable lands in urban areas, brownfield regeneration has become significant aspect of sustainable urban development [5], [10] [12]. Latvia is no exception and the issue of brownfield regeneration and redevelopment remain one of the greatest challenges for local municipalities. Over the last decade, the regeneration of abandoned, derelict and often contaminated territories, has become essential to improve the quality of urban environment and to ensure sustainable development strategy of the Daugavpils city.

Indisputable, existence of brownfields on the administrative area makes it unattractive for investors and residents, but as redevelopment of such sites are not possible without significant investments, they are rarely being re-used. Despite this fact, recent economic growth and access to the European Union structural funds has result in risen interest to regeneration processes in Baltic States. [6]

As pointed out by several authors, location related aspects of brownfield sites (geographical location, existence of transportation links, socio-demographic structure of locals, economic potential, economic activity and unemployment rate etc.) plays an important role in their regeneration processes [1], [9], [13]. Nevertheless, such site-specific factors as size of brownfield, its previous use, number of buildings, ownership relations etc. also are crucial for planning brownfield redevelopment projects in administrative territory [1], [13].

Many authors emphasized various benefits of brownfield redevelopment, including improvement of city attractiveness and livability, increase in tax incomes and property value, as well as, reducing level of crime and others [2], [20], [21].

This paper analyses the spatial patterns of postsocialist deindustrialization and brownfield regeneration in Daugavpils city. The aim of the current study is to explore the characteristics of the brownfield sites and their spatial patterns in Daugavpils. Thus, the research contributes to an understanding of post-socialist urban transformations by clarifying the spatial patterns of urban brownfields behind the massive deindustrialization of the 1990s. The paper addresses two main research questions. First, how the brownfield sites are spatially http://dx.doi.org/10.17770/etr2017vol1.2589 
distributed across the city? Second, what are the characteristics of the surveyed sites in terms of current use? The second question draws particular attention on urban brownfields regeneration

\section{MATERIALS AND METHODS}

Since the paper aims to explore the characteristics of the brownfield sites and their spatial patterns, the research calls for use of various information sources and methodological approaches, from spatial analyses to qualitative investigation. Methodologically, the paper emphasizes case study research, which illustrates distinct types of brownfield sites in the city.

\section{Study area}

Daugavpils, the second-tier city in Latvia, is the case study for analyzing the post-socialist deindustrialization and spatial patterns of urban brownfields. In Daugavpils, there is a long history of industry dated back to the 19th century, but in the Soviet Union the city was strongly industrialized. During the Soviet-era industrialization and inmigration, Daugavpils had grown conspicuously. After the collapse of the Soviet Union, many industrial enterprises were forced to close production, simultaneously, large number of construction projects remained unfinished [14]. Nowadays, most of industrial territories in the city remain abandoned. [15] The city's population has declined from over 126,000 in 1990 to approximately 85,000 inhabitants in 2016. However, Daugavpils today still is an important industrial center and transportation hub with regional administrative and servicing functions.

Inventorying

Previous studies indicate [2], [13], that brownfield management in any particular area begins with inventorying of the brownfields and creation of database followed by processes of brownfield assessment and classification according to regeneration options, environmental risk and other criteria. Most common way of brownfield identification process depends on available data sources, such as inventories of contaminated and abandoned territories, property tax records or existing redevelopment projects [16]. Within this research a request for the relevant information has been sent to the local municipality. As a result, information about potential brownfield sites was compiled from Daugavpils City Urban Planning and Construction Department's list of 50 abandoned properties. However, the data gained from the municipality were updated several years ago and did not include all the potential brownfield sites. Therefore, detailed inventory of the most densely populated neighborhood Jaunā Forštate was implemented. During the survey 11 additional brownfield sites were identified.

In summary, analysis was based on the following data sources: (1) Daugavpils City Urban Planning and
Construction Department's list of 50 abandoned territories, created in 2013 year and updated in 2014; (2) data gained from detailed inventory of the neighborhood Jaunā Forštate implemented in the end of 2015. All previously mention data was updated during fieldwork in 2015/2016 study year, as well as by gathering information from database of contaminated territories, cadastral systems and during the meetings with local government experts.

Additional information about regenerated brownfield was gained from analysis of Google View images taken in years 2011 and 2012. Most often these images helped to identificate redevelopment option of specific site.

Site survey and creation of database

The present paper and data analysis is based on information obtained during the fieldwork. Unlike similar studies [2], [3], which were based on existing inventory data, this research includes identification of potential brownfield sites within the city during the field work and creation of database, including all necessary data for further spatial analysis. All the identified potential brownfield sites were surveyed during the fieldwork. Assessment criteria were in line with previous research [17], which is modified by taking into account relevant literature [16], [18] and expert opinion obtained during the interviews with local government experts. As a result, all the 61 surveyed sites are classified as existing or regenerated brownfields. Property are identified as brownfield based on four criteria: hazard, efficiency of the use, negative impact on the landscape and pollution.

Spatial analysis of the data

Geographic information systems has been widely used for spatial analysis and management of brownfields, evaluation of regeneration projects and creation of cartographic material for informative purposes. Within the current research the geodatabase of brownfield sites was created based on field work and various secondary data sources.

Geographic information system software ArcGIS $\mathrm{ESRI}^{\mathrm{TM}} 10$ is used for collection, processing and compilation of the database. For visualization of these data and it further analysis following layers were used: spatial structures of Daugavpils city, city neighborhoods, city boundary, main transportation axes and main railways conducted in previous study by Sergejs Trošimovs [19].

Spatial analysis of the data relies on information gathered in the database. Brownfield spatial patterns were evaluated depending on their site- specific characteristics, such as classification, location in Daugavpils city districts, ownership, previous use, planned use, number of buildings etc.

\section{RESULTS AND DISCUSSION}

According to the data gained form local government and fieldwork, there is at least 61 brownfield sites in the city of Daugavpils. Eleven of 
them are successfully regenerated, while 50 remain abandoned (classified as existing brownfields). Study results indicates that existing brownfields covers 36 ha or $0.5 \%$ of total city area. It is significant, that almost half of the Daugavpils city territory consists of water and green spaces, respectively brownfield areas cover $1 \%$ of the Daugavpils city built-up areas.

The distribution of analyzed brownfields is spatially uneven (Fig. 1). In relation to spatial structures of the city, $2 / 3$ of both existing and regenerated brownfields are located in residential areas, while reminding number of territories is evenly distributed among industrial zones and downtown area. Regardless the fact that $62 \%$ of existing brownfields are located in residential areas, the biggest coverage $(70 \%$ or 26 ha) of brownfield sites are detected in industrial zones of the city.

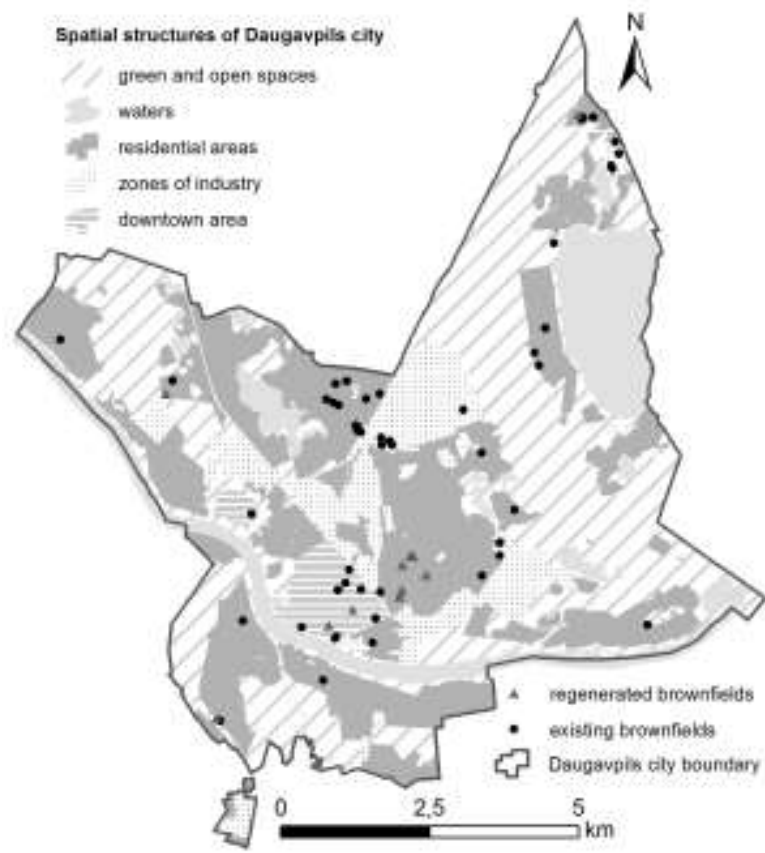

Fig. 1. The location of surveyed brownfield sites in spatial structures of Daugavpils city. Graphic elaboration by author.

While analyzing size and structure of the brownfields, becomes clear, that, the biggest and the most complex sites are located exactly in industrial zones, contrariwise, in residential and downtown areas mostly are positioned relatively small sites or even individual buildings. Research indicates, that size and complexity of the brownfield site is one of the important factors in brownfield revitalization process in Daugavpils, as most of regenerated brownfields are demolished or restored sites with total area less than 0.2 ha, while none of previous industrial sites and vacant factory complexes was fully regenerated.

In regard to further revitalization projects, it is important to state that $2 / 3$ of analyzed existing brownfields are relatively small and covers less than 0.5 ha. Most of these territories are individual buildings $(30 \%)$ or small cadastral units with some build-up area (61\%). In total, build-up area covers half of existing brownfield territory and $82 \%$ of it is located in industrial zones. As industrial sites include plenty of supporting constructions, brownfields of this type consists of multiple buildings (at this research number of building in industrial sites vary from 1 to 9).

During the research, there were identified 112 abandoned buildings in existing brownfield sites. Despite the fact that time period when these buildings were put into exploitation vary from beginning of $19^{\text {th }}$ century till the early 2000 s, significant majority $(72 \%)$ were constructed in the period of Soviet Union. This highlights fact already pointed out by several authors [4] - [9], that recent societal and economic transitions in the city result in increasing number of brownfields.

Original use of brownfield sites in Daugavpils city also reflects to changing economic situation in the city. With transition from post-soviet economic model, large factories were closed, what alongside with migration of workers caused abandonment of sites used for housing (38\%), industry $(20 \%)$ and commercial $(20 \%)$ purposes (Table 1$)$.

Table 1.

Original use of brownfields in Daugavpils city

\begin{tabular}{lllll}
\hline & \multicolumn{5}{c}{ Number of brownfields } \\
\cline { 2 - 5 } Original use & Total & Downtown & $\begin{array}{l}\text { Residential } \\
\text { areas }\end{array}$ & $\begin{array}{l}\text { Industrial } \\
\text { zones }\end{array}$ \\
\hline $\begin{array}{l}\text { Housing } \\
\text { sites } \\
\begin{array}{l}\text { Commercial } \\
\text { sites }\end{array}\end{array}$ & 23 & 6 & 17 & 0 \\
$\begin{array}{l}\text { Industrial } \\
\text { sites } \\
\text { Sites of } \\
\text { public } \\
\text { importance }\end{array}$ & 12 & 2 & 9 & 1 \\
$\begin{array}{l}\text { Information } \\
\text { is not } \\
\text { available }\end{array}$ & 5 & 1 & 1 & 9 \\
\hline $\begin{array}{l}\text { Restored } \\
\text { sites }\end{array}$ & 11 & 2 & 8 & \\
\hline
\end{tabular}

Results of the study indicate that brownfields located in downtown were previously used for diverse purposes. Residential areas concentrate biggest number of brownfields, that originally was used for housing, though number of sites constructed for commercial and public use are also significant. In context of brownfield revitalization, it is important to mention, that 9 from 11 analyzed regenerated brownfields included buildings previously used for housing purposes. Revitalization of these sites mostly was conducted in the most primitive way -8 from these sites were demolished and only one multistorey building in city center were restored for further commercial purpose.

One more important site-specific factor, connected with planning revitalization options for the brownfield in Daugavpils city is ownership [1], [2]. 
According to legislation, owner is responsible for maintenance and management of brownfields in the administrative territory, so realization of any potential revitalization projects depends on owner's engagement. Collapse of socialism and following privatization processes during the end of $20^{\text {th }}$ century resulted in diverse structure of brownfield ownership in Daugavpils city (Table 2). Most of existing and regenerated brownfields $(36 \%)$ covering large areas in the city of Daugavpils are owned by legal person, these mostly are industrial and commercial sites.

Table 2.

Ownership relations of brownfields in Daugavpils city

\begin{tabular}{lllll}
\hline & \multicolumn{5}{c}{ Number of brownfields } \\
\cline { 2 - 5 } Ownership & Total & $\begin{array}{l}\text { Existing } \\
\text { brownfields }\end{array}$ & $\begin{array}{l}\text { Regenerated } \\
\text { brownfields }\end{array}$ & $\begin{array}{l}\text { Brownfield } \\
\text { area (ha) }\end{array}$ \\
\hline Foreigner & 1 & 1 & 0 & 0,05 \\
$\begin{array}{l}\text { Individual } \\
\text { Mixed status }\end{array}$ & 10 & 7 & 3 & 2,2 \\
$\begin{array}{l}\text { of co- } \\
\text { ownership }\end{array}$ & 11 & 7 & 4 & 0,9 \\
$\begin{array}{l}\text { Legal } \\
\text { person }\end{array}$ & 22 & 19 & 3 & 23,8 \\
Municipality & 11 & 10 & 1 & 2,4 \\
\begin{tabular}{l} 
State \\
\hline
\end{tabular} & 6 & 6 & 0 & 8,0 \\
\hline
\end{tabular}

Significant number of brownfield (15\%) has mixed status of co-ownership, which usually results in difficulties during revitalization processes, as there appears need in owners' collaboration and common brownfield management vision. Despite this fact, exactly these brownfields mostly are regenerated, that can be related to relatively small area of these sites. However, territories or their undivided shares owned by foreigners represents a regeneration barrier. Generally, connection between ownership and location of brownfields within the city has been not found, nevertheless, sites owned by municipality and state mostly are located in residential $(65 \%)$ or industrial (29\%) areas.

From spatial development perspective, it is easier to attract investors for the brownfield there mixed type of construction is permitted, thereby investors have freedom to choose further usage of the site. According to data gathered during this research, significant number $(20 \%)$ of both existing and regenerated brownfields in Daugavpils are located in the area for mixed constructions (Table 3), however, regenerated was mostly territories located in residential areas. This can be explained by the fact, that complex regeneration projects in Daugavpils has been conducted rarely, instead, revitalization is simply organized by demolishing low-rise residential buildings or renovation of individual buildings for further commercial use. Near-future challenge is to encourage complex revitalization of industrial and commercial territories which occupied more than half of total brownfield area.
Table 3.

Planned/allowed use of brownfields in Daugavpils city

\begin{tabular}{lllll}
\hline \multirow{2}{*}{$\begin{array}{l}\text { Planned/allowed } \\
\text { use }\end{array}$} & \multicolumn{5}{c}{ Number of brownfields } \\
\cline { 2 - 5 } & Total & $\begin{array}{l}\text { Existing } \\
\text { brownfields }\end{array}$ & $\begin{array}{l}\text { Regenerated } \\
\text { brownfields }\end{array}$ & $\begin{array}{l}\text { Brownfield } \\
\text { area (ha) }\end{array}$ \\
\hline $\begin{array}{l}\text { Area for } \\
\text { residential } \\
\text { buildings }\end{array}$ & 30 & 20 & 10 & 4,0 \\
$\begin{array}{l}\text { Area for mixed } \\
\text { construction }\end{array}$ & 12 & 11 & 1 & 8,6 \\
$\begin{array}{l}\text { Area for } \\
\text { business object }\end{array}$ & 7 & 7 & 0 & 3,4 \\
$\begin{array}{l}\text { Area for } \\
\text { industrial } \\
\text { objects }\end{array}$ & 6 & 6 & 0 & 18,4 \\
$\begin{array}{l}\text { Area for objects } \\
\text { of public }\end{array}$ & 5 & 5 & 0 & 2,9 \\
$\begin{array}{l}\text { importance } \\
\text { Area for } \\
\text { transport } \\
\text { maintenance } \\
\text { objects }\end{array}$ & 1 & 1 & 0 & 0,001 \\
\hline
\end{tabular}

The distribution of brownfields reflects to both historical development of the city and proximity to city center and main transportation axes.

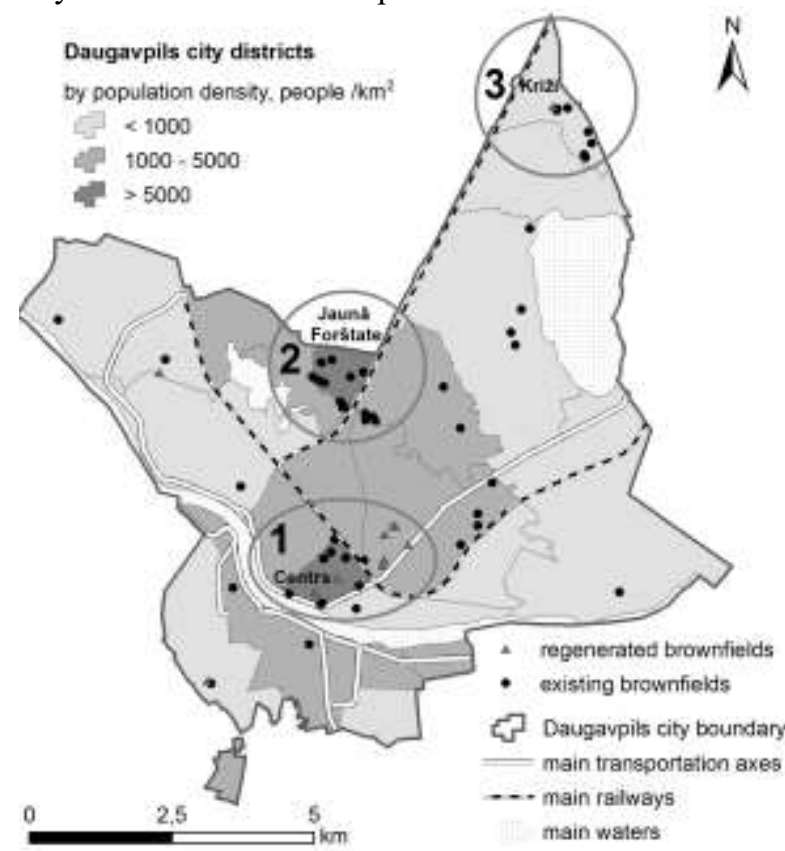

Fig. 2. The location of surveyed brownfield sites depending on population density and main transportation corridors. Graphic elaboration by author.

Three main clusters of brownfields can be identified (Fig. 2): (1) central and wider inner-city area concentrates most of brownfields with various types of use, including two thirds of all regenerated sites; (2) as a result of detailed inventory of the most densely populated neighborhood Jaunā Forštate, significant number of brownfields are located there; (3) remarkable number of brownfield sites is situated in the most remote city neighborhood Križi. While brownfields previously used for housing and commercial use or as public facilities are mostly located in densely populated neighborhoods of the 
city, location of post-industrial brownfields is influenced by proximity of transportation axes. Fact mentioned above also reflects to recent transition from soviet economic model based on economic collaboration with other post-soviet countries and widely developed transportation network.

As mentioned above, regenerated sites are mostly located in densely populated areas within wider inner-city (Fig. 2) Local authorities recognizes, that most of regenerated sites were demolished or renovated due to complains of local residents, that lead to the fact, that locals are willing to increase livability of a particular neighborhood by engaging in urban spatial development planning.

\section{CONCLUSION}

Results of this study indicates, that Daugavpils, as most of post-soviet cities, have a great influence from collapse of Soviet Union. As a consequence of economical and societal changes in the city during the 1990s, a lot of brownfield sites emerge. More than half of area covered by brownfield sites have postindustrial origin and is situated in industrial zones in direct proximity to transportation corridors. Alongside with a rapid decrease in population in the end of $20^{\text {th }}$ century [19] in downtown and residential areas of Daugavpils city a lot of abandoned and/or unfinished housing, commercial and public facilities remained. Original use of brownfields in Daugavpils city stipulates uneven distribution of these sites in the city, as most of them are abandoned buildings previously used for industrial and commercial activities substantially located in densely populated or industrial part of the city.

As evidenced in many studies, location of brownfield sites directly affects their redevelopment potential [1], [2], [13]. This study emphasizes that brownfields located in more attractive central areas of the city with good transportation links and economic potential are most likely to be regenerated thanks to both involvements of local residents and attraction of investors.

However, engagement of investors in redevelopment projects also highly depends on such site-specific factors as size, complexity and original use of the brownfield, ownership relations, as well as planned/allowed use of the site. While smaller housing or commercial properties with less complex ownership status makes regeneration process more likely to be implemented, huge industrial complexes usually privatized by several owners by definition have difficulties with revitalization processes. As these post-industrial sites are mostly located in industrial zones of the city surrounded by transportation axes, stimulation of regeneration processes can be implemented by creating favorable conditions for further investors, for example, by allowing wider possibilities for further use of the site. With transition from secondary to tertiary economic investors are most likely to invest in commercial or sites with mixed use, rather than in industrial zones.

Higher number of brownfield regeneration have been detected in densely built-up areas close to the inner-city, while lower rates were found for areas with low population density at the periphery of the city. As indicated by local authorities, redevelopment of brownfields often is an initiative of local residents willing to improve attractiveness and livability of a particular neighborhood. As noted by several authors, revitalization of brownfields sites results in already mentioned benefits, as well as in reducing level of crime and increasing property value [20], [21].

The results presented in this paper are based on survey of 61 brownfield sites in Daugavpils, which reflects only part of real situation within the city. Detailed inventory of all neighborhoods with following update in database of existing and regenerated brownfields is necessary for more detailed study.

\section{REFERENCES}

[1] J. Hercik, P. Šimáček, Z. Szczyrba, I. Smolová, "Military brownfields in the Czech Republic and the potential for their revitalisation, focused on their residential function," Quaestiones Geographicae, vol. 33, pp. 127-138, Mar. 2014.

[2] B. Frantál, J. Kunc, E. Nováková, P. Klusáček, S. Martinát, R. Osman, "Location matters! Exploring brownfields regeneration in a spatial context (case study of the South Moravian Region, Czech Republic)," Moravian geographical reports, vol. 21, pp. 5-19, 2013.

[3] J. Kunc, S. Martinat, P. Tonev, B. Frantal, "Destiny of urban brownfields: spatial patterns and preceived consequences of post-socialistic deindustrialization," Transylvanian Review of Administrative Sciences, vol. 41, pp. 109-128, 2014.

[4] R. Osman, B. Frantal, P. Klusacek, J. Kunc, S. Martinat, "Factors affecting brownfield regeneration in post-socialist space: The case of the Czech Republic," Land Use Policy, vol. 48, pp. 309-316, Jun. 2015.

[5] Y. Liu, F. van Oort, S. Geertman, Y. Lin, "Institutional determinants of brownfield formation in Chinese cities and urban villages," Habitat International, vol. 44, pp. 72-78, May 2014.

[6] J. Tintera, A. Ruus, E. Tohvri, Z. Kotval, "Urban brownfields in Estonia: scope, consequences and redeveloment barriers as perceived by local governments," Moravian Geographical Reports, vol. 22, pp. 25-38, 2014.

[7] E. Rizzo, M. Pesce, L. Pizzol, F. M. Alexandrescu, E. Giubilato, A. Critto, A. Marcomini, S. Bartke, "Brownfield regeneration in Europe: Identifying stakeholder perceptions, concerns, attitudes and information needs," Land Use Policy, vol. 48, pp. 437-453, Jun. 2015.

[8] L. Pizzol, A. Zabeo, P. Klusacek, E. Giubilato, A. Critto, B. Frantal, S. Martinat, J. Kunc, R. Osman, S. Bartke. "Timbre Brownfield Prioritization Tool to support effective brownfield regeneration," Journal of Environmental Management, vol. 166, pp. 178-192, 2016.

[9] S. Martinat, P. Dvorak, B. Frantal, P. Klusacek, J. Kunc, J. Navratil, R. Osman, K. Tureckova, M. Reed, "Sustainable urban development in a city affected by heavy industry and mining? Case study of brownfields in Karvina, Czech Republic," Journal of Cleaner Production, vol. 118, pp 78-87, Jan. 2016.

[10] K. J. Doick, G. Sellers, V. Castan-Broto, T. Silverthorne, "Understanding success in the context of brownfield greening projects: The requirement for outcome evaluation in urban greenspace success assessment," Urban Forestry \& Urban Greening, vol. 8, pp. 163-178, 2009. 
[11] M. Morio, S. Schädler, M. Finkel. “Applying a multi-criteria genetic algorithm framework for brownfield reuse optimization: Improving redevelopment options based on stakeholder preferences," Journal of Environmental Management, vol. 130, pp. 331-346, Oct. 2013.

[12] Z. Kramárová, "Brownfield Topic in the Czech Legislation," Procedia Engineering, vol. 161, pp. 290-293, 2016.

[13] B. Frantál, B. Greer-Wootten, P. Klusáček, T. Krejčí, J. Kunc, S. Martinát, "Exploring spatial patterns of urban brownfields regeneration: The case of Brno, Czech Republic," Cities, vol. 44, pp. 9-18, Jan. 2015.

[14] L. Kilevica, Daugavpils. Rīga: Jumava, 2006.

[15] "Daugavpils pilsētas attīstības programma 2014.-2020. gadam. Vides pārskats," [Online]. Available: https://www.daugavpils.lv/upload/2014_doc/Vides_parskats RP gala $\% 2020 \% 2002 \% 202014 . p d f$ [Accessed: Mar. $\overline{14}$, 2017].

[16] F. Cheng, S. Geertman, M. Kuffer, Q. Zhan, “An integrative methodology to improve brownfield redevelopment planning in Chinese cities: A case study of Futian, Shenzhen.
Computers," Environment and Urban Systems, vol. 35, pp. 388-398, Jun. 2011.

[17] L. Žukovska, "Degradēto būvju un teritoriju novērtēšanas metodikas izstrāde un aprobācija Cēsu pilsētā”, Maǵistra darbs, Latvijas Universitāte, Rīga, 2013.

[18] M. Chrysochoou, K. Brown, G. Dahal, C. Granda-Carvajal, K. Segerson, N. Garrick, A. Bagtzoglou, "A GIS and indexing scheme to screen brownfields for area-wide redevelopment planning," Landscape and Urban Planning", vol. 105, pp. 187198, Jan. 2012

[19] Trošimovs, "Ieteikumi Daugavpils pilsētas telpiskās attīstības perspektīvas izstrādei," Maǵistra darbs, Daugavpils Universitāte, Daugavpils, 2014.

[20] A. S. Abd Elrahman, "Redevelopment Aspects for Brownfields sites in Egypt," Procedia Environmental Sciences, vol. 34, pp. 25-35, 2016.

[21] L. Loures, E. Vaz, "Exploring expert perception towards brownfield redevelopment benefits according to their typology," Habitat International, to be published, pp, 1-11, 2016. 